\title{
Interpretation of genotype $x$ environment interaction and stability analysis for grain yield of pigeon pea (Cajanus cajan $\mathrm{L}$.
}

\author{
B. Arunkumar ${ }^{1 *}$, S. Muniswamy ${ }^{2}$ and P.S. Dharmaraj ${ }^{2}$ \\ ${ }^{1}$ Agricultural Research Station, Bidar-585 401 (Karnataka), INDIA \\ ${ }^{2}$ Agricultural Research Station, Gulbarga-585 101 (Karnataka), INDIA \\ *Corresponding author. E-mail: b.arunkumar@rediffmail.com \\ Received: August 21, 2014; Revised received: October 16, 2014; Accepted: December 02, 2014
}

\begin{abstract}
Fourteen pigeon pea (Cajanus cajan L.) genotypes were evaluated for their yield performance at two locations during kharif season of 2009-10 and 2010-11. A significant genotypic difference for yield character was observed. Highly significant genotype-environment interaction indicated differential response of the genotypes to the environmental changes. The stability analysis showed significance of linear component of variation for grain yield. The genotypes TJT-501 $(1728.667 \mathrm{Kg} / \mathrm{Ha})$ and GRG-2009-3 $(1570.000 \mathrm{Kg} / \mathrm{Ha})$ exhibited low mean performance along with regression value nearer to unity $(\mathrm{bi}=1)$ and non significant deviation from regression $\left(S^{2} \mathrm{di}=0\right)$ indicating, the high stability and wider adaptability across the different environments. The genotype ICPH-2671 $(3134.833 \mathrm{Kg} / \mathrm{Ha})$ exhibited highest mean value and regression value (bi>1) and non significant deviation $\left(S^{2} \mathrm{di}<0\right)$. But genotypes JKM-197 (3072.667 Kg/ha), GRG-2009 (29993.167 Kg/ha), TS-3R (2823.333 Kg / Ha) and ICP-8863 $(2740.417 \mathrm{Kg} / \mathrm{Ha})$ exhibited high mean performance but higher regression value (bi $>1)$ and significant deviation $\left(S^{2}\right.$ di $\left.<0\right)$ value indicating adapted for high performance environments showing these genotypes are sensitive to environments and give maximum yield when inputs are not limited.
\end{abstract}

Keywords: Cajanus cajan, Environment interaction, Genotype , Pigeonpea, Stability

\section{INTRODUCTION}

Pigeonpea (Cajanus cajan.L.) is the important grain legume. It is cultivated in varied agro climatic conditions ranging from moisture stress and input starved conditions to irrigated conditions. Selection and yield testing are the two major phases of varietal development and the later one is highly influenced by the locations and years of testing. The genotype $\mathrm{x}$ environment $(\mathrm{G} \times \mathrm{E})$ interactions can be defined as differential phenotypic response of genotypes to environmental changes and quantified using several procedures, all of which are based on evaluation of genotypes under multiple environments (Tolessa, et. al, 2013). The final yield of a genotype is determined by interaction of genotype with prevailing environment. By providing suitable environment, the maximum yield potential from a particular crop variety can be released. Hence, it is, necessary to determine the environment which may allow full expression of genes controlling the quantitative traits. To plan the future breeding program, to determining the environment and number of tests to be conducted for evaluation of the prepotency of the breeding material developed, the degree of genotype environment interaction involved in the expression of given characters is very much important (Thanki et al., 2010).

Stability is the ability to show a minimum interaction with the environment (Eberhart and Russell,1966).
Hence, the stability of genotype performance is directly related to the effect of $\mathrm{G} \times \mathrm{E}$ (Campbell and Jones, 2005). The adaptability of a variety over diverse environments is usually tested by the degree of its interaction with different environments under which it is tested (Finlay and Wilkinson, 1963). A genotype is considered to be more adaptive/stable one, if it has high mean yield but a low degree of fluctuation in yielding ability when grown over diverse environments. A specific genotype does not always exhibit the same phenotypic traits under all environments and different genotypes respond differently to specific location (Sawargaonkar et al., 2011).

Therefore, knowledge of $\mathrm{G} \times \mathrm{E}$ interaction and yield stability are important for breeding new cultivars with improved adaptation to environmental constraints prevailing in the target environments. The present research study was conducted to know genotype-environment interaction and to identify stable and high yielding pegion pea genotypes under changing environments.

\section{MATERIALS AND METHODS}

Fourteen pigeon pea genotypes were evaluated at two locations viz., Agricultural Research Station, Bidar, (North eastern transitional zone- 1) having medium black clay laterite soil and Agricultural Research Station, Gulbarga. (North eastern dry zone-2) consisting of deep black soil during Kharif 2009-10 and 2010-11 to 
study the stability of seed yield The experiments were laid out in randomized block design with three replications, keeping row and plant distance at 90 and $30 \mathrm{~cm}$, respectively. Recommended package of practices were followed for raising the good crop. The crop was harvested at the time of $90 \%$ pod maturity. Data was collected for seed yield per plot from two locations during both years and converted to $\mathrm{Kg} / \mathrm{ha}$. The data was analyzed and stability parameters were estimated as suggested by Eberhart and Russell, 1966 using computer software written in "INDOSTAT"

\section{RESULTS AND DISCUSSION}

Phenotypically stable varieties are usually sought for commercial production of crop plants. In any breeding program it is necessary to screen and identify Phenotypically stable genotypes, which could perform more or less uniformly under different environmental conditions. Considering this fact in mind, the present investigation was carried out to collect information on newly developed and some released genotypes of pigeon pea which may be of great use in launching a dynamic and efficient breeding programme.

The analysis of variance for seed yield displayed significant differences among locations, years, genotypes and location $\mathrm{x}$ year, location $\mathrm{x}$ genotype and location $\mathrm{x}$ year $\mathrm{x}$ genotype interactions and significant for year $\mathrm{x}$ genotype interactions advocating the adequacy of stability analysis (Table 1). This showed that the genotypes were not only genetically variable but some of them also exhibited different response to variable environments (locations and years). The partitioning in pooled analysis of variance showed that genotype $\mathrm{x}$ environments interaction was significant (Table1). Environment linear and genotypes $\mathrm{x}$ environment linear were highly significant. Ch.Sreelakshmi et al. (2010) and Reddy et al. (2011) reported highly significant genotype $x$ environment $(G$ $\mathrm{x} E$ ) interaction in pigeonpea
Eberhart and Russel (1966) and Westerman (1971) emphasized that both linear (bi) and non-linear $\left(\mathrm{S}^{2} \mathrm{di}\right)$ components of $\mathrm{G} \times \mathrm{E}$ interaction should be considered in judging the phenotypic stability of a particular genotype. From the ANOVA table, the value for the Genotype X Environment (linear) sum of squares was not as a large portion of the $\mathrm{G} \times \mathrm{E}$ interaction, when compared with the environment $\mathrm{E}$ (linear) sum of squares and the residual. Table 1 shows the variation among the genotypes and for $\mathrm{G} \times \mathrm{E}$ interaction was significant. It means that genotypes exhibited different performance in different years /environments which is due to their different genetic makeup or the variation due to the environments or both.

The environmental indices for seed yield are presented in Table 2. The location, Agricultural Research Station (ARS), Gulbarga was the most favourable environment for the better expression of trait as revealed by high and positive environmental indices during both the years 2009-10 (560.526) and 2010-11 (876.642). While, the location, ARS, Bidar was the most unfavourable environment due to high negative environmental indices during both the years 2009-10 (-702.048) and 2010-11 (-735.120).Genotypes GRG-2009 (5073.333 Kg/Ha), JKM-197 (4980.000 Kg/Ha), TS 3R (4726 Kg/Ha) and ICPH 2671 (4386.667 Kg/Ha), JKM-19 (3856.667 $\mathrm{Kg} / \mathrm{Ha}$ ) and GRG-2009 (3760.000) were the promising genotypes respectively during 2009-10 and 2010-11 at ARS , Gulbarga. At Agricultural Research Station, Bidar, ICP-8863 (1786.667 Kg/Ha ) followed by JKM-197 $(1770.000 \mathrm{Kg} / \mathrm{Ha})$ and ICP-85063 $(1746.667 \mathrm{Kg} / \mathrm{Ha})$ were promising genotypes in the year 2009-10 and in 2010-11, promising genotypes were ICPH-2671 (1782.667 Kg/Ha) followed by JKM-197 (1684.000) and ICPL-87119 (1613.667 Kg/Ha) (Table 2).

According to Eberhart and Russell (1966) model of stability analysis, a stable variety is one which has above average mean yield, a regression coefficient of

Table 1. Pooled analysis of variance for seed yield of pigeon pea.

\begin{tabular}{lllll}
\hline Source of variance & DF & Sum of squares & Mean sum of squares & F ratio \\
\hline Replication with error & 8 & 274555.66991 & 34319.45874 & 0.195 \\
Genotype & 13 & 30962797.65511 & $2381753.66578 * * *$ & 13.500 \\
Environment $+($ Genotype & 42 & 50937514.12359 & $1212797.95532 * * *$ & 6.874 \\
$\times$ Environment) & 3 & 29623483.26006 & $9874494.42002 * * *$ & 55.968 \\
Environment & 39 & 21314030.86353 & $546513.61189 * *$ & 3.098 \\
Genotype $\times$ Environment & 1 & 29623483.26006 & $29623483.26006 * * *$ & 167.903 \\
Environment (Linear) & 13 & 16373940.32422 & $1259533.87109 * * *$ & 7.139 \\
Genotype $\times$ Environment (Linear) & 28 & 4940090.53931 & $176431.80498 * * *$ & 4.202 \\
Pooled deviation & 104 & 4366589.27686 & $41986.43535 * * *$ & $1489096.57779 * * *$ \\
Pooled error & 55 & 81900311.77870 & & \\
Total & 5 & &
\end{tabular}

* Significance at $5 \%$ level; ** Significance at $1 \%$ level 
Table 2. Mean performance (seed yield, $\mathrm{Kg} / \mathrm{Ha}$ ) of pigeon pea cultivars over the environments.

\begin{tabular}{|c|c|c|c|c|c|c|c|}
\hline \multirow[t]{2}{*}{ Genotype } & \multicolumn{2}{|c|}{ ARS, Bidar } & \multicolumn{2}{|c|}{ ARS, Gulbarga } & \multirow[t]{2}{*}{ Mean } & \multirow[t]{2}{*}{ bi } & \multirow[t]{2}{*}{$\mathrm{S}^{2} \mathrm{di}$} \\
\hline & $2009-10$ & $2010-11$ & 2009-10 & $2010-11$ & & & \\
\hline TS-3 ( R ) & 1616.667 & 1590.000 & 3360.000 & 4726.667 & 2823.333 & 1.760 & 126953.818 \\
\hline JKM-197 & 1770.000 & 1684.000 & 3856.667 & 4980.000 & 3072.667 & 1.913 & 27606.959 \\
\hline GRG-2009 & 1636.667 & 1502.667 & 3760.000 & 5073.333 & 2993.167 & 2.033 & 74918.703 \\
\hline ICP-8863 & 1786.667 & 1425.000 & 3070.000 & 4680.000 & 2740.417 & 1.664 & 283297.442 \\
\hline ICPL-87119 & 1363.333 & 1613.667 & 3343.333 & 4006.667 & 2581.750 & 1.533 & -10659.274 \\
\hline ICPH-2671 & 1650.000 & 1782.667 & 4386.667 & 4720.000 & 3134.833 & 1.951 & -11090.615 \\
\hline ICP-85063 & 1746.667 & 1609.000 & 3063.333 & 630.000 & 1762.250 & -0.066 & 1453218.351 \\
\hline GRG-2009-1 & 1383.333 & 1175.000 & 2015.000 & 1824.000 & 1599.333 & 0.422 & -5111.376 \\
\hline GRG-2009-3 & 1053.333 & 1153.333 & 1891.000 & 2182.333 & 1570.000 & 0.655 & -35930.734 \\
\hline TAT-9903 & 1270.000 & 1158.333 & 1977.000 & 1882.000 & 1571.833 & 0.480 & -23600.320 \\
\hline JKE-114 & 1076.667 & 960.000 & 2020.000 & 1693.333 & 1437.500 & 0.546 & 24747.483 \\
\hline TJT-501 & 1240.000 & 991.667 & 2313.333 & 2369.667 & 1728.667 & 0.839 & -18168.149 \\
\hline GC-11-39 & 980.000 & 1250.000 & 839.697 & 1252.000 & 1080.424 & -0.018 & 21322.018 \\
\hline ICPL-87 & 686.667 & 901.667 & 1040.000 & 1341.667 & 992.500 & 0.290 & -17602.156 \\
\hline $\begin{array}{l}\text { Environmental } \\
\text { index }\end{array}$ & -702.048 & -735.120 & 560.526 & 876.642 & & & \\
\hline $\mathrm{CV} \%$ & 15.240 & 14.448 & 20.482 & 12.216 & & & \\
\hline $\mathrm{CD} @ 5 \%$ & 351.882 & 325.569 & 906.905 & 605.729 & & & \\
\hline
\end{tabular}

unity (bi=1) and non significant mean square for deviations from regression $\left(S^{2} \mathrm{di}=0\right)$. High value of regression (bi>1) indicates that the variety is more responsive for input rich environment, while, low value of regression (bi<1), is an indication that the variety may be adopted in poor environment. The phenotypic stability of genotypes was estimated by mean performance over years (x), the regression coefficient (b) and deviation from regression.

Based on stability parameters, the genotypes TJT-501 $(1728.667 \mathrm{Kg} / \mathrm{Ha})$ and GRG-2009-3 (1570.000 Kg/Ha) exhibited low mean performance along with regression value nearer to unity $(\mathrm{bi}=1)$ and non significant deviation from regression $\left(\mathrm{S}^{2} \mathrm{di}=0\right)$ indicating the high stability and wider adaptability across the environments. Similarly, Ch.Sreelakshmi et al. (2010) in their studies on genotype $\mathrm{X}$ environment interaction and stability in white seeded Pigeon pea found genotypes ICPL 6628, ICPL-7527 and ICPL-7534 showed stable performance across environments.

The genotype ICPH-2671 (3134.833 Kg/Ha) exhibited highest mean value and bi values (bi>1) and non significant deviation $\left(S^{2} \mathrm{di}<0\right)$ but genotypes JKM-197 (3072.667 $\mathrm{Kg} / \mathrm{ha})$, GRG-2009 (29993.167 Kg/ha),TS-3R $(2823.333 \mathrm{Kg} / \mathrm{Ha})$ and ICP-8863 (2740.417 Kg/Ha) exhibiting high mean performance but bi $>1$ and significant deviation $\left(S^{2}\right.$ di $\left.<0\right)$ value indicating adapted for high performance environments (Table 2). Similarly, Patel, et.al., (2009) reported pigeonpea genotypes SKNP-9264 and SKNP-9256 had high mean and significant deviation $\left(\mathrm{S}^{2} \mathrm{di}<0\right)$ in their study.

\section{Conclusion}

It was concluded that none of the genotypes studied was found superior for all yield in all the environments. The genotypes TJT-501 and GRG-2009-3 exhibited low mean with regression value nearer to unity and non significant deviation from regression indicating, high stability and wider adaptability. Genotypes JKM-197, GRG-2009,TS-3R and ICP-8863 exhibiting higher mean and regression value and significant deviation value, but the genotype ICPH-2671 exhibited highest mean and regression and non significant deviation value indicating adapted for high performance environments. The stable genotypes identified could be used as parents in future breeding programme for developing suitable genotypes with wider adaptability.

\section{REFERENCES}

Campbell, B.T. and Jones, M.A. (2005). Assessment of genotype $\times$ environment interactions for yield and fibre quality in cotton performance trials. Euphytica, 144: 69-78.

Ch.Sreelakshmi, Shivani, D. and Sameer Kumar, C.V. (2010). Studies on genotype $X$ environment interaction and stability in white seeded Pigeon pea (Cajanus cajan L.) genotypes, Legume Res., 33(3): 217 - 220.

Eberhart, S.A. and Russell, W.A. (1966). Stability parameters for comparing varieties. Crop Science, 6:36-40.

Finlay, K.W. and Wilkinson, G.N. ( 1963). The analysis of adaptation in a plant breeding programme. Australian J. Agric. Res., 14:742-754.

Patel P.T. Chauhan R.M. Parmar, L.D and Tikka S.B.S. 
(2009), Phenotypic Stability of Yield and Related Traits in Pigeonpea. Legume Res., 32(4) : 235-239

Reddy D. Kodanda Rami, Venkat sarlu, O., Obai ah M.C., Jyothi G.L. Siva, (2011). Genotype x Environment Interaction for Grain Yield and its Components in Red gram [Cajanus Cajan (L.) Millsp] Legume Rsearch - An International Journal 34(4), 288-291

Sawagaonkar, S.L, Saxena K.B, MadrapaI.A, and Rathore A, ( 2011) Stability Analysis of yield and related traits in pigeonpea hybrids.J.Legume Res.4:184-193

Tolessa, T., Gemechu Keneni, Tadese Sefera, Mussa Jarso and Yeneneh Bekele,(2013), Genotype x environment interaction and perfaormamnce stability for grain yield in Field pea (Pisum sativum L.) genotypes. Int.J.plant Breeding, 7 (2) 116-123,

Thanki, H.P. Sawargaonkar S.L. and Hudge, B.V. ,2010, Genotype $\mathrm{x}$ environment interaction for biometrical traits in pigeonpea (Cajanus cajan L. Millsp.) under varying spacings, Electronic J. Plant Breeding, 1(4): 925-928

Westerman, J.M. (1971). Genotype x Environment interaction and developmental regulation in Arabidopsis thaliana II. Inbred lines analysis. Heredity, 26: 93-106. 